\title{
SISTEM PENDUKUNG KEPUTUSAN \\ UNTUK MENENTUKAN DOSIS OBAT PADA ANAK \\ MENGGUNAKAN METODE FORWARD CHAINING (Studi Kasus Di Klinik Dokter Umum Karanggayam - Srengat)
}

\author{
${ }^{[1]}$ Udkhiati Mawaddah, ${ }^{[2]}$ Muchtar Fauzi \\ ${ }^{[1],[2]}$ Universitas Islam Balitar Blitar
}

\begin{abstract}
Abstrak: Pembahasan utama dalam skripsi ini adalah perancangan dan pembuatan sistem pendukung keputusan dengan metode forward chaining. Penelitian dalam skripsi ini menggunakan subjek penyakit anak dan dosis obat anak karena penentuan jenis penyakit dan dosis obat pada anak yang dilakukan sebelumnya masih ditentukan oleh dokter sendiri.Metode yang digunakan dalam pembuatan sistem pendukung keputusan ini adalah forward chaining untuk menentukan jenis penyakit pada pasien, di mana sistem digerakkan oleh fakta-fakta yang ada. Fakta tersebut diperoleh dari kondisi fisik pasien, atau disebut dengan gejala. Dalam pembuatan sistem pendukung keputusan ini diperlukan penggalian data yang bersumber pada pakar, dalam hal ini adalah dokter. Proses pengujian sistem pendukung keputusan ini menggunakan angket. Berdasarkan hasil kuisioner, sistem pendukung keputusan ini memiliki prosentase kemudahan program untuk digunakan oleh pengguna adalah sebesar 48,8\%. Selain itu kesesuaian program ini juga mendapatkan prosentase yang besar juga.
\end{abstract}

Kata Kunci : Sistem Pendukung Keputusan, Runut Maju, Dosis Obat, Diagnosis Penyakit Anak.

\section{Pendahuluan}

Era globalisasi,informasi, dan komunikasi membawa dampak di berbagai bidang kehidupan manusia.Dampak tersebut terlihat dengan adanya kemajuan teknologi pada berbagai bidang, antara lain bidang komputer. Komputer merupakan kumpulan perangkat keras dan lunak yang mempermudah melaksanakan pekerjaan manusia guna mempercepat dalam suatu pengambilan keputusan. Hampir semua kehidupan manusia dapat memanfaatkan keberadaan komputer, sehingga pekerjaan menjadi lebih efisien dan akurat. Pengambilan keputusan yang tepat dan cepat diperlukan pada suatu aktivitas untuk menyelesaikan suatu permasalahan. Terutama untuk pemilihan penyakit dan obat pada sebuah klinik kesehatan, agar permasalahan sedikitnya jam praktek dokter dan kurangnya tenaga ahli untuk menentukan diagnosis dan dosis obat anak bisa teratasi. Karena pengambilan keputusan yang tepat akan sangat berpengaruh pada proses selanjutnya (Turban, 2007).

Berdasarkan latar belakang yang telah disebutkan, maka tujuan dalam penelitian ini adalah untuk merancang danmembangun sebuah aplikasi sistem pendukung keputusan penentuan dosis obat pada anak. Serta untuk menerapkan metode forward chaining pada aplikasi sistem pendukung keputusan penentuandosis obat pada anak. Batasan penelitian meliputi tempat penelitian di klinik dr.Ainur Rofiq di Desa Karanggayam Kecamatan Srengat Blitar. Sistem yang dibahas hanya tentang penghitungan dosis obat berdasarkan kriteria berat badan pasien.Sistem yang dibuat di khususkan pada pemilihan dosis obat untuk anakanak.Penyakit anak yang di bahas dalam penelitian ini meliputi penyakit ispa, penyakit kulit, 
diare, typhoid, dan asma.Jika penyakit tidak terdeteksi oleh sistem, maka langsung ditanyakan kepada pakar/dokter.

Decision Support Systematau Sistem Pendukung Keputusan yang selanjutnya kita singkat dalam proposal ini menjadi SPK, secara umum didefinisikan sebagai sebuah sistem yang mampu memberikan kemampuan baik kemampuan pemecahan masalah maupun kemampuan untuk mengkomunikasianmasalah semi-terstruktur. Secara khusus, SPK didefinisikan sebagai sebuah sistem yang mendukung kerja seorang manajer maupun sekelompok manajer dalam memecahkan masalah semi-terstruktur dengan cara memberikan informasi ataupun usulan menuju pada keputusan tertentu (Hermawan, 2005).

Menurut Giarratano dan Riley (2005), forward chaining adalah salah satu metode dari sistem pakar yang mencari atau menelusuri solusi melalui masalah. Dengan kata lain metode ini melakukan pertimbangan dari fakta-fakta yang kemudian berujung pada sebuah kesimpulan yang berdasarkan pada fakta-fakta. Metode ini merupakan kebalikan dari metode backward chaining yang melakukan pencarian yang berawal dari hipotesis menuju ke faktafakta untuk mendukung hipotesis tersebut. Pada metode forward chaining, penjelasan tidak terlalu terlalu terfasilitasi karena subgoals tidakdiketahui secara eksplisit sebelum kesimpulannya ditemukan.Forward chaining disebut juga bottom-up reasoning atau pertimbangan dari bawah ke atas, karena metode ini mempertimbangkan dari bukti-bukti pada level bawah, fakta-fakta, menuju ke kesimpulan pada level atas yang berdasarkan pada fakta-fakta.

BasisDataadalah suatu susunan atau kumpulandatayangdisatukan didalamsuatu organisasiatau perusahaanyang diorganisirataudikeloladandisimpansecara terintegrasidenganmenggunakan metode tertentumenggunakan Komputersehingga mampumen2yediakaninformasioptimalyangdiperlukanpemakainya. Menurut Bunafit Nugroho (2008 : 2) XAMPP Merupakankepanjangan dari Apache, PHP, MySQLdan PhpMyAdmin. XAMPPmerupakantoolyangmenyediakanpaketperangkatlunakkedalam satu buah paket. Dengan menginstall XAMPPmaka tidak perlu lagi melakukan instalasi dan konfigurasi web server Apache, $P H P$ dan $M Y S Q L$ secara manual. XAMPP akan menginstalasi dan mengkonfigurasikannyasecara otomatis untuk anda atau auto konfigurasi.

$X A M P P$ merupakan pengembangan dari LAMP(Linux Apache, MySQL, PHP and PERL), XAMPP ini merupakan project non-profit yang di kembangkan oleh Apache Friends yang didirikan Kai 'Oswalad' Seidler dan Kay Vogelgesang pada tahun 2002, project mereka ini bertujuan mempromosikan pengunaan Apache web server.XAMPP adalah software web server apache yang di dalamnya tertanam server MySQL yang didukung dengan bahasa pemrograman PHP untuk membuat website yang dinamis. XAMPP sendiri dapat berjalan pada berbagai macam platform seperti Windows, Linux, Mac OS X dan Solaris.

Java merupakan bahasa pemrograman berorientasi objek daan bebas platform, dikembangkan oleh SUN Micro System dengan jumlah keunggulan yang memungkinkan java dijadikan sebagai bahasa pengembang entreprise. Java merupakan bahasa yang powerfull yang bisa digunakan dalam hampir semua bentuk pengembangan software. Anda dapat menggunakan java untuk membuat game, aplikasi desktop, aplikasi web, aplikasi enterprise, aplikasi jaringan, dan lain-lain. Yang menarik adalah bahwa java bias digunakan untuk membuat laporan yang dapat berjalan di atas HP, PDA, dan peralatan lain yang dilengkapi dengan Java Virtual Machine (JVM) (Andi, 2006).

SQL (Structured Query Language) adalah bahasa standart yang digunakan untuk mengakses server database. Semenjak tahun 70-an bahasa ini telah dikembangkan oleh IBM, yang kemudian diikuti dengan adanya Oracle, Informix dan Sybase. Dengan menggunakan SQL, proses akses database menjadi lebih user-friendly dibandingkan dengan misalnya dBase ataupun Clipper yang masih menggunakan perintah - perintah pemrograman murni (Sunarfrihantono. 2002). 
NetBeans merupakan salah satu IDE yang dikembangkan dengan bahasa pemrograman java. NetBeans mempunyai lingkup pemrograman java terintergrasi dalam suatu perangkat lunak yang di dalamnya menyediankan pembangunan pemrograman GUI, text editor, complier, dan interpreter. NetBeans adalah sebuah perangkat lunak open source sehingga dapat digunakan secara gratis untuk keperluan komersial maupun nonkomersial yang didukung oleh Sun Microsystem (Andi, 2006).

Dosis obat adalah obat yang diberikan pada penderita dalam satuan berat(gram,milligram,mikrogram) atau satuan isi (milliliter,liter) atau unit-unit lainnya (unit internasional). Kecuali bila dinyatakan lain maka yang dimaksud dengan dosis obat adalah sejumlah obat yang memberikan efek terapuetik pada penderita dewasa juga disebut dosis lazim atau dosis medicinalis atau dosis terapuetik (Nanizar, 2001:46).

\section{Metode Penelitian}

\section{A. Lokasi dan waktu Penelitian}

Adapun Waktu yang digunakan dalam penelitian ini selama 2 minggu mulai tanggal 1 Juni 2016 sampai tanggal 15 Juni 2016. Penelitan dilakukan di klinik dokter Ainur Rofiq yang beralamatkan di Desa Karanggayam Kecamatan Srengat Kabupaten Blitar.

\section{B. Pengumpulan Data}

Dalam pengumpulan skripsi ini, diperlukan data-data serta informasi yang relatif lengkap sebagai bahan yang dapat mendukung kebenaran materi dan uraian dan pembahasan. Oleh karena itu, sebelum penyusun skripsi ini dilakukan riset atau penelitian terlebih dahulu untuk menjaring data serta informasi yang terkait. Tahap pengumpulan data pada penelitian ini dilakukan dengan metode observasi, wawancara, studi pustaka, dan studi literatur.

\section{Perancangan Sistem}

\section{Flowchart Sistem}

\section{Keterangan :}

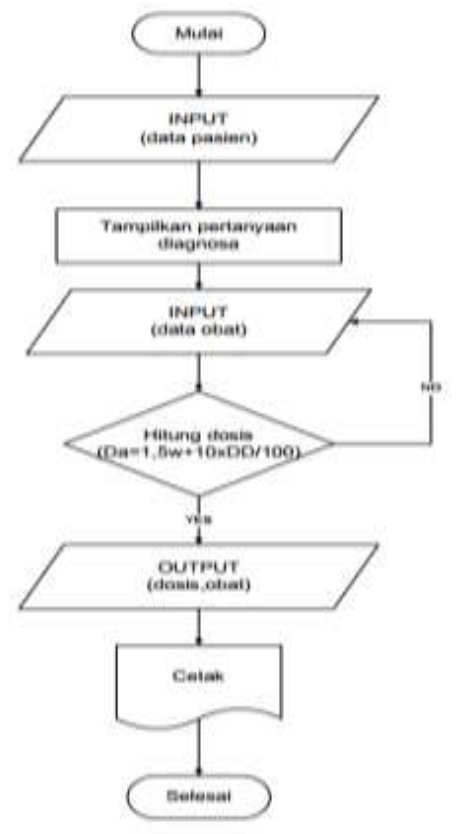

Gambar 1 Flowchart Sistem

$\mathrm{Da}=$ dosis anak

$\mathrm{W}=$ berat badan anak

$\mathrm{Dd}=$ dosis dewasa 
Dalam gambar 1 flowchart sistem dimulai dari dashboard yang merupakan menu utama, selanjutnya masuk ke halaman pendataan pasien, pengguna mendata pasien sesuai data pasien. Kemudian pengguna memilih halaman diagnosis penyakit dan menanyakan gejala yang sesuai dengan apa yang dirasakan oleh pasien, selanjutnya apabila penyakit sudah terdiagnosis dengan metode forward chaining, pengguna langsung cek data obat sesuai penyakit yang di derita pasien. Jika obat tidak tersedia atau habis pengguna langsung inputkan obat pengganti yang tersedia, selanjutnya pengguna bisa melakukan perhitungan dosis obat dan menampilkan hasil akhir berupa dosis obat untuk pasien.

\section{Flowchart Forward chaining}

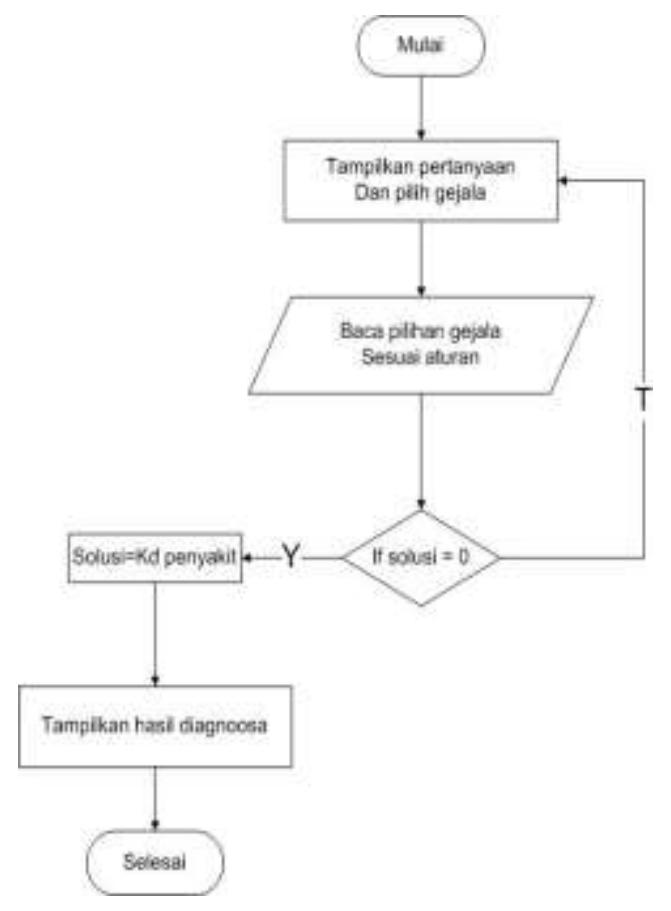

Gambar 2 FlowchartForward chaining

Gambar2 flowchart dimulai dari menu start diagnosis, selanjutnya muncul tampilan pertanyaan gejala penyakit yang ditanyakan pengguna kepada pasien, setelah pertanyaan gejala di jawab sesuai aturan metode forward chainingmaka akan munculsolusi, jika tidak terdeteksi maka akan kembali ke pertanyaan awal, dan jika terdeteksi maka akan muncul kode penyakit dan hasil diagnosis akan tampil.

Berikut akan dijabarkan mengenai daftar penyakit anak pada tabel 1 :

TABEL 1

DAFTAR PENYAKIT ANAK

\begin{tabular}{cccc}
\hline Kode Penyakit & Nama Penyakit & Kode Penyakit & Nama Penyakit \\
\hline P1 & Bronkiolitis & P10 & Asma \\
\hline P2 & Pneumonia & P11 & Cacar air \\
\hline P3 & Tonsilitis & P12 & Dermatitis \\
\hline P4 & Bronchitis & P13 & Campak keringat \\
\hline P5 & Diare & P14 & Gondongan \\
\hline P6 & Typhoid & P15 & Flu singapur \\
\hline P7 & Meningitis & P16 & Dbd \\
\hline P8 & Laringitis & P17 & Kejang
\end{tabular}




\section{Diagram konteks}

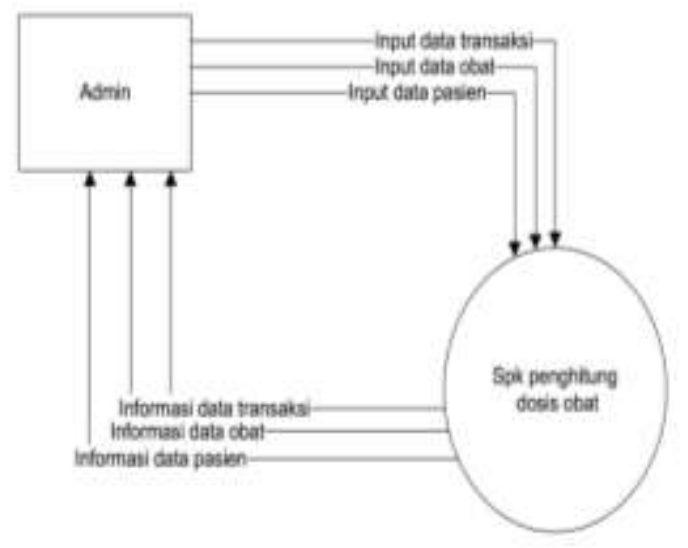

Gambar 3 Diagram konteks

Pada gambar 3 dijelaskan terdapat satu entity yang terhubung dengan sistem pendukung keputusan perhitungan dosis obat, yaitu user. User akan memasukkan berbagai macam data yang mendukung jalannya aplikasi ini. Data yang dimasukkan antara lain data pasien, data obat, dan data transaksi. Sehinggapengguna dapat menghitung dosis obat yang mereka kehendaki, serta melihat menu pilihan lainnya.Informasi lain yang tersedia diharap mampu memenuhi kebutuhan klinik dalam proses peracikan obat.

\section{Perhitungan Dosis}

Contoh kasus, Anita umur 7tahun ,berat badan $20 \mathrm{~kg}$ menderita demam, nafsu makan berkurang, gelisah, dispnea (Sesak napas), pilek, dan batuk kering.

Penyeleseian :

Tentukan jenis penyakit dulu lewat rule menggunakan metode forward chaining

IF demam

AND nafsu makan berkurang

AND sesak nafas (dispensia)

AND pilek

AND batuk kering

THEN ISPA (bronkiolitis)

Jika sudah diketahui jenis penyakit maka akan muncul obat untuk penyakit jenis ISPA bronkiliotis = amoksisilin $500 \mathrm{mg}$, parasetamol $500 \mathrm{mg}$, ambroxol $30 \mathrm{mg}$ dan ctm $4 \mathrm{mg}$.

Selanjutnya penghitungan dosis berdasarkan berat badan menggunakan rumus Augeberger (Nanizar,2001).

$\mathrm{F}(\mathrm{x})=\frac{1 \frac{1}{2} \mathrm{xBB}+10}{100} \mathrm{xDD}$

amoksisilin $=\left(\frac{1 \frac{1 / 2}{2} 20+10}{100}\right) \times 500 \mathrm{mg}=200 \mathrm{mg} \times 10=2000 \mathrm{mg}$

parasetamol $=\left(\frac{1 \frac{1}{2} \times 20+10}{100}\right) \times 500 \mathrm{mg}=200 \mathrm{mg} \times 10=2000 \mathrm{mg}$

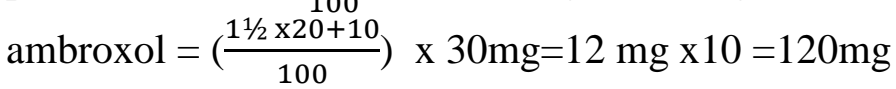

$\mathrm{ctm}=\left(\frac{1 \frac{1 / 2}{2} 20+10}{100}\right) \times 4 \mathrm{mg}=1,6 \mathrm{mg} \times 10=16 \mathrm{mg}$

Kesimpulan : jadi dosis maksimal untuk pasien Anita jika berdasarkan berat badan adalah $200 \mathrm{mg}$ parasetamol, $200 \mathrm{mg}$ amoksisilin, $12 \mathrm{mg}$ ambroxol, 1,6 mg ctm untuk satu kali minum. 


\section{A. Tampilan Program}

\section{Hasil Dan Pembahasan}

\section{Halaman Utama}

Pada halaman utama ini berisikan tentang semua hal yang berhubungan dengan klinik. Mulai dari data pasien, data obat, dan data transaksi .

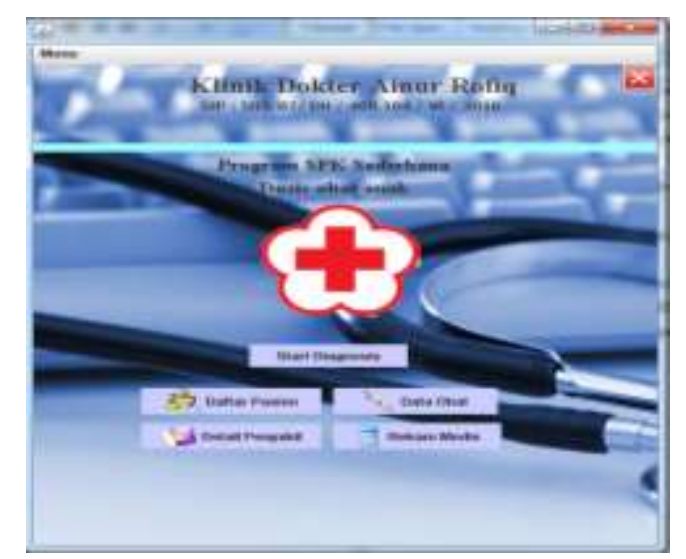

Gambar 4Halaman utama

\section{Tampilan daftar pasien}

Halaman data pasien berisikan tentang data - data pasien yang baru atau pasien lama.

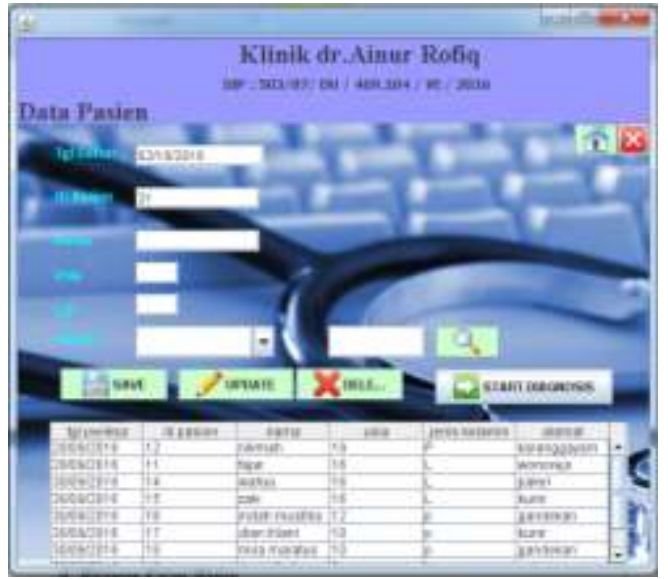

Gambar 5 Halaman daftar pasien

\section{Tampilan halaman diagnosis}

Pada halaman ini pengguna menanyakan gejala yang diderita oleh pasien. Data yang didapat dari pasien akan menuju pada kesimpulan diagnosis penyakit. 


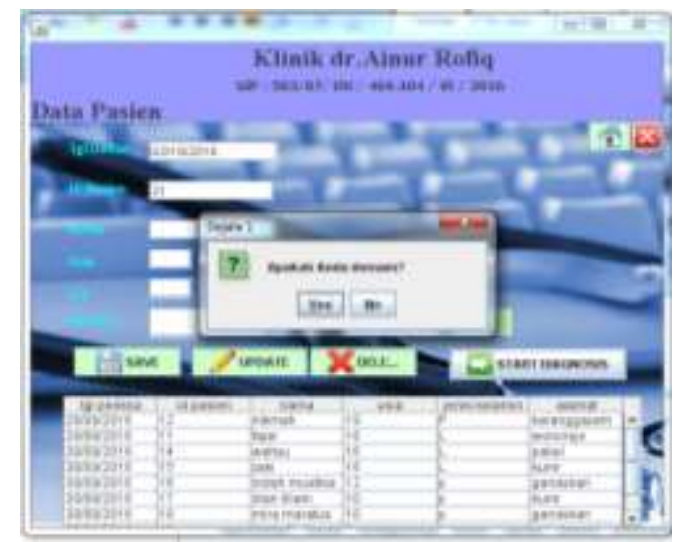

\section{Halaman data obat}

\section{Gambar 6Halaman diagnosis}

Pada halaman data obat, pengguna dapat menambah atau mengubah data obat sesuai dengan penyakit dan persediaan obat di klinik dr.Ainur Rofiq.

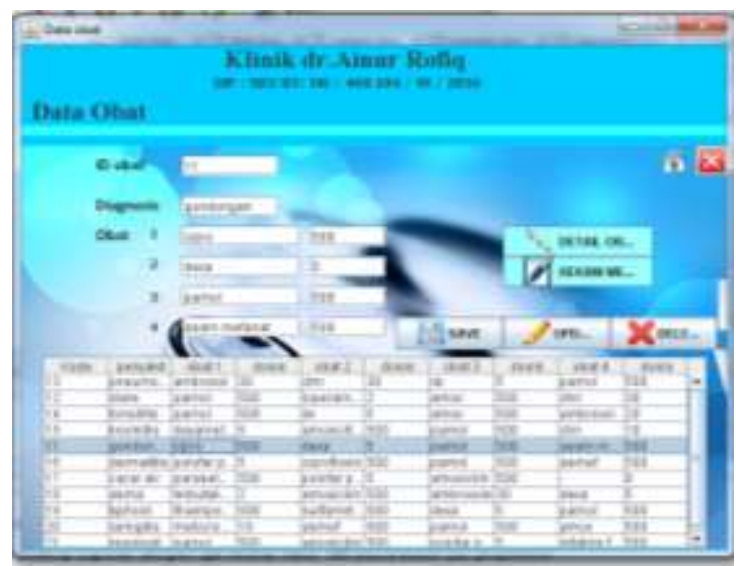

Gambar 7Halaman data obat

\section{Tampilan halaman transaksi}

Halaman Transaksidigunkan untuk menentukan dosis obat berdasarkan berat badan pasien yang rumus perhitungannya telah ditentukan oleh dokter ahli. Dari halaman inilah pengguna dapat menghitung dosis obat setelah setelah mendapat data yang telah diinputkan sebelumnya.

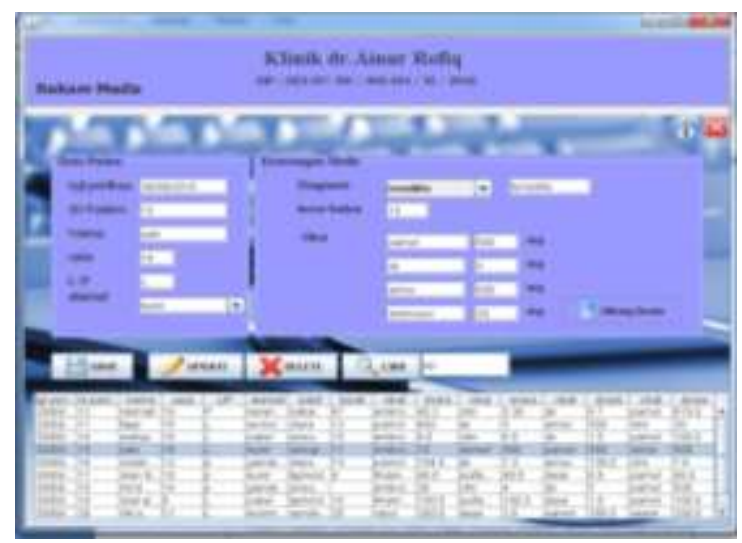

Gambar 8Halaman transaksi 


\section{Halaman laporan}

Halaman laporan merupakan halaman yang dapat dicetak. Ada tiga pilihan report dalam halaman laporan. Pertama laporan data pasien yang di cetak berdasarkan id pasien. Untuk laporan data pasien bisa dilihat pada gambar 9. Kedua pada laporan transaksi yang berisi semua data pasien yang berkunjung di klinik dr.Ainur Rofiq yang dapat dilihat pada gambar 10. Dan yang ketiga untuk cetak kartu berobat pasien pada gambar 11.

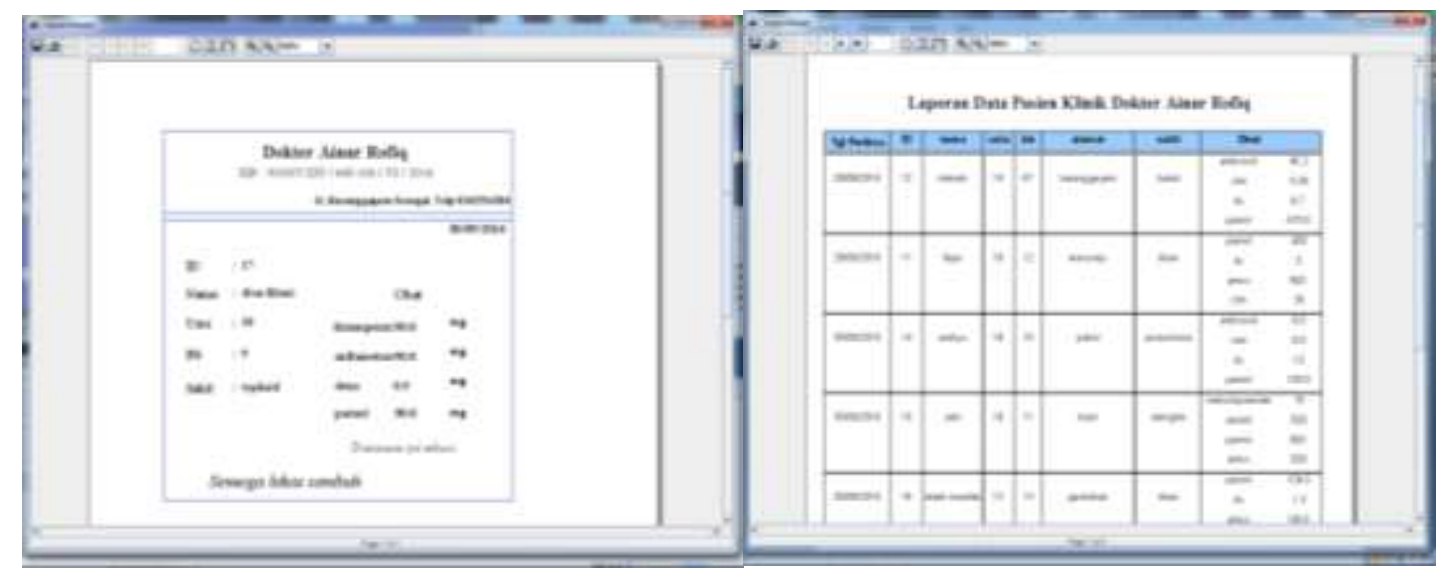

Gambar 9 Laporan Data PasienGambar 10 Laporan Data Transasksi

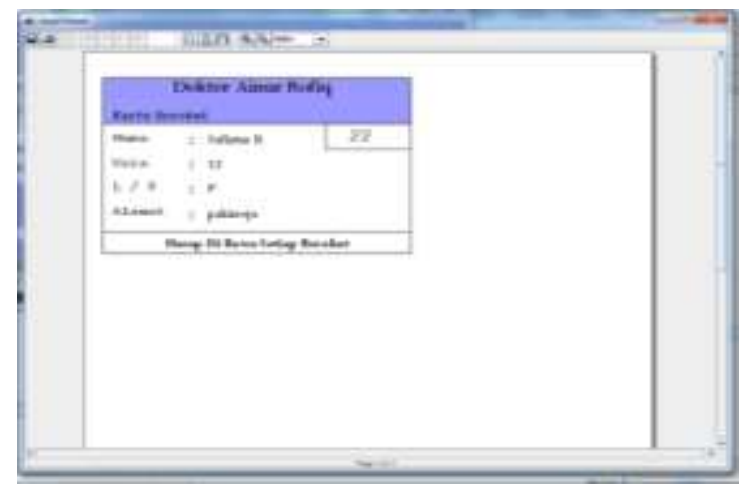

Gambar 11 Halaman Cetak Kartu

\section{B. Pengujian Sistem}

Metode pengujian yang digunakan pada penelitian skripsi ini menggunakan dua cara, yang pertama menggunakan metode Black Box dan yang kedua menggunakan Pengujian Beta.

a. Metode Pengujian Black Box adalah metode pengujian yang menguji fungsionalitas sistem. Metode tersebut dilakukan untuk memastikan apakah fungsi berjalan dengan benar jika diberikan masukan yang bervariasi. Sistem penelusuran ini berjalan dengan baik sesuai dengan fungsinya

b. Pengujian Beta merupakan pengujian yang dilakukan secara obyektif dimana diuji secara langsung kelapangan yaitu instansi yang bersangkutan dengan membuat kuesioner mengengai kepuasan user dengan kandungan point syarat user friendly dan dibagikan kepada sebagian user dengan mengambil sampel sebanyak 20 orang.

Data dari kuesioner tersebut akan direkap menjadi satu, kemudian dicari presentasenya, untuk mencari presentase jawaban yang diberikan responden penulis menggunakan rumus seperti yang dikemukakan oleh wahyu winarno (2010)

$$
\text { Prosentase }=\frac{\text { Jumlah }}{\text { Nilai Total }} \times 100 \%
$$


Jumlah diperoleh dari penjumlahan nilai semua responden yang diambil perkriteria, sedangkan pada nilai total diperoleh dari jumlah nilai akumulasi dari semua responden pada bobot penilaian sangat baik, baik, cukup, kurang untuk masing-masing aspek pada tabel kuesioner.

Berdasarkan hasil kuisioner dapat ditarik kesimpulan bahwa dilihat dari segi Desain Sistem diperoleh penilaian Baik dengan persentase pengujian awal sebesar $40.6 \%$ dan dari pengguna $48.8 \%$, sedangkan aspek Kesesuaian Sistem memperoleh penilaian Baik juga dengan hasil persentase pengujian awal sebesar $42.6 \%$ dan dari pengguna $47.8 \%$ dan aspek Kemudahan Sistem dinilai Sangat Baik dengan presentase pengujian awal sebanyak $57.9 \%$ dan dari pengguna sebesar $58.4 \%$.

\section{A. Simpulan}

\section{SiMPULAN DAN SARAN}

Proses mulai dari perancangan sistem sampai pengujian aplikasi yang dilakukan dapat diambil beberapa kesimpulan sebagai berikut:

1. Implementasi sistem ini dibuat menggunakan pemrograman berbasis dekstop, sehingga sistem mudah dijangkau dan digunakan oleh user. Sistem ini diterapkan di klinik dokter umum untuk mendiagnosis penyakit dan menghitung dosis obat pada anak. Berdasarkan hasil pengujian desain sistem ini memperoleh penilaian Baik dengan prosentase pengujian awal sebesar $40.6 \%$ dan dari pengguna $40.8 \%$, sedangkan aspek Kesesuaian Sistem memperoleh penilaian Baik juga dengan hasil porsentase pengujian awal sebesar $42.6 \%$ dan dari pengguna $47.8 \%$ dan aspek Kemudahan Sistem dinilai Sangat Baik dengan prosentase pengujian awal sebanyak $57.9 \%$ dan dari pengguna sebesar $58.4 \%$.

2. Penerapan metodeforward chaining pada pembuatan Aplikasi Sistem Pendukung Keputusan penentuan dosis obat pada anak di gunakan membantupenelusuran penyakit agar hasil diagnosis lebih akurat. Kesesuaian sistem ini mendapatkan nilai baik dengan prosentase pada pengujian awal sebesar $42.6 \%$ dan $47.8 \%$ dinyatakan oleh pengguna.

\section{B. Saran}

Berdasarkan analisis dan kesimpulan dari laporan ini, beberapa saran yang ingin disampaikan antara lain:

1. Sistem ini masih sangat sederhana, maka kedepannya dibutuhkan inovasi baru sehinga bisa menghasilkan output yang lebih komplek tidak hanya sekedar perhitungan dosis obat.

2. Perancangan sistem ini masih menggunakan basis desktop, untuk kedepannya diharapkan bisa dijalankan secara online maupun bentuk aplikasi yang dapat diunduh pada smartphone.

\section{Daftar Pustaka}

Alimul, H.Aziz.A.2005.Pengantar ilmu keperawatan anak 1, Jakarta: Salemba Medika.

Andi. Membuat Aplikasi Database dengan Java 2, Semarang : PT. Wahana Komputer. 2006.

Endang,M. 2013.Sistem Pendukung Keputusan Klinis Anak Batuk Berbasis Algoritma MTBS,skripsi.Yogyakarta:kedokteran.

Firebaugh, 2007. Artificial Intelligence: A knowledge - Based Approach.Boston: PWSKENT Publishing Company.

Ganiswarna, 2012. Farmakologi dan Terapi, Bagian Farmakologi Fakultas Kedokteran Universitas Indonesia, Jakarta. 
Giarratano, J. C. dan Riley, G. D. 2005. Expert Systems Principles and Programming Fourth Edition:167-173.Boston: Course Technology.

Joenoes, Nanizar Zaman. 2001. Ars Prescribendi (II). Surabaya: Airlangga University press.

Ofiana,R.2016. Pembuatan sistem pakar diagnosa penyakit infeksi saluran pernafasan atas (ISPA) berbasis desktop dengan menggunakan metode forward chaining,Skripsi.Yogyakarta: STIMIK AMIKOM.

Turban, \& Efraim, 2007.Decision Support and Expert System. New Jersey: Prentice Hall

Sudarmana,Landung.2015.Sistem Pendukung Keputusan menentukan dosis obat secara rasional pada penyakit pernafasan, ISBN: 978-602-1180-21-1 - Fakultas Teknik Universitas Muria Kudus (345-350). Prosiding SNATIF Ke -2 . 